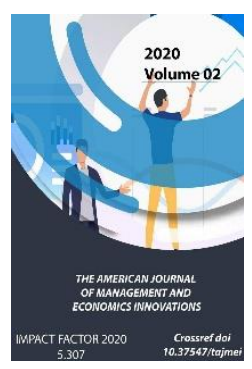

\title{
Factors Influencing The Sustainable Expansion Of Small Business Entities And Opportunities For Their Effective Use
}

Juraxanov Muzaffar Eskandarovich

Andijan Machine - Building Institute, Uzbekistan

Copyright: Original

content from this work

may be used under the

terms of the creative

commons attributes

4.0 licence.

\section{ABSTRACT}

The article deals with the analysis of the factors influencing the sustainable development of small business. At the same time, the indicators of sustainability of small businesses in Andijan region are analyzed and the opportunities for their effective use are highlighted.

\section{KEYWORDS}

Small business, sustainable development, sustainable development factors, external and internal factors, finance, taxation, investment, organization, production-technological, environmental, sociodemographic, innovation, geographical factors, infrastructure.

\section{INTRODUCTION}

It is known that in recent years in Uzbekistan, priority is given to the development, promotion and support of small business and private entrepreneurship, which play an important role in ensuring the sustainable growth of employment and income. In this regard, the "Action Strategy for the five priority areas of development of the Republic of Uzbekistan for 2017-2021", developed on the initiative of President Sh.M.Mirziyoyev, provides for the protection of private property rights and further strengthening its priority, small business Encouraging the development of private entrepreneurship is an important task, which shows the urgency of this issue. The experience of developed countries shows that small business needs to be developed due to the nature of the optimal and rational use of resources. 
Sustainable development of small business means a positive change in the quantitative and qualitative aspects of the industry in the long run. It is also based on the efficient and rational use of factors of production. This requires special attention to factors in the study of the issue of sustainable development of small business.

Based on the opinions of E.A. Lyamanova, K.V. Kolpakova, E.V. Gusarova, "natural resource potential, infrastructure, environmental, sociodemographic, innovation, geographical factors, local and state policies are recognized as factors influencing the sustainable development and competitiveness of small business.

Lino Marquez Coimbra links the sustainable development of entrepreneurship to internal and external environmental factors. Internal environmental factors include, first of all, the level of quantity and quality of the individual, his qualifications, organizational and cultural characteristics of the business structure. External factors include the socio-economic, political, legal and cultural conditions necessary for the functioning of the business structure.

According to the opinion of A. Savichev, the factors affecting the development and stability of small and medium-sized businesses are divided into two types, namely, external and internal. External factors include sociopolitical, economic-technological and conjunctural factors, while internal factors include organizational-social (management structure, development strategy, sociopsychological environment) and socioeconomic (production, innovation, labor and financial factors) factors.

As mentioned above, L.M. Shahshayeva also said that the sustainable development of small business depends on external and internal factors, which include:

1. Financial support mechanisms, tax crediting;
2. Normative and legal regulation of activity, study of legal bases;

3. Financial cooperation;

4. Business insurance;

5. Formation of information

6. $\quad$ infrastructure;

At the same time, the research conducted by $A$. Safina and M. Gayfullina listed such factors as financial, tax, investment, organizational, production and technological as factors of sustainable development of small enterprises. Also, according to the results obtained, financial and investment factors were considered as sources of strong influence.

P. V. Ivaniy, on the other hand, cited financial resources as a key factor in the sustainable development of small business. According to the author, lending and investing in the activities of small businesses is a key source of sustainable development.

Uzbek scientists K. Karimova and K. Sharifkhodjaeva focused on financial resources, among the factors affecting small business. In particular, in their research, they focused on the experience of small business financing, lending and concessions in foreign countries.

The number of small businesses in Andijan region, their share in industries and sectors is growing every year. Moreover, the share of the final product of the regional economy - GRP and employment is growing. In particular, in 2019, the share of small business in the region's GRP amounted to 71.4 percent, which is 1.3 times more than in 2010. At the same time, the small business level is evolving in terms of quantity and quality. At the same time, the rational and efficient use of resources is a key issue on the agenda. That is, increasing the efficiency of factors of production will ensure sustainable development and economic development of the industry. This allows the development of appropriate proposals by identifying the relative advantages of districts 
and cities based on an assessment of the current situation.

In assessing the economic stability of small businesses operating in Andijan region, the indicators of economic, social, institutional, external economic and financial stability were studied separately. At the same time, the indicators of small businesses in the region for 2010-2019 were studied.

In the process of assessing economic stability, the situation in the regional sectors was studied. The highest values of stability indicators in the industrial sector were in Bulakbashi (0.83), Pakhtaabad (0.82),
Shahrikhan (0.81), Balikchi (0.75) and Khojaabad (0.74) districts. The smallest unit was detected in Asaka (0.05) district. Based on our research, it was found that the cities of Andijan and Khanabad are close to the average values (Table 1 ).

The reason for the fact that in the process of assessing the stability of the industrial sector reflects the smallest units of indicators in the cities of the region, it can be said that in these areas are located mainly large industrial enterprises. This requires diversification of enterprises in these regions and the development of integration between large and small businesses.

Table 1

The level of economic stability of small businesses in the districts and cities of Andijan region

\begin{tabular}{|c|c|c|c|c|c|c|c|c|}
\hline & 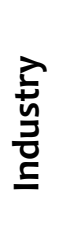 & $\frac{\frac{0}{3}}{\frac{\underline{x}}{3}}$ & 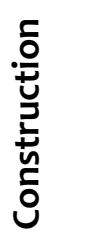 & 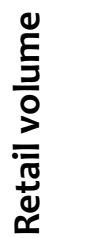 & $\frac{y}{\frac{.}{2}}$ & $\begin{array}{l}\frac{\infty}{n} \\
. \frac{1}{n} \\
\frac{n}{n} \\
\frac{n}{n}\end{array}$ & 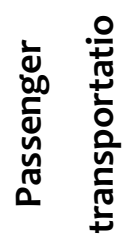 & 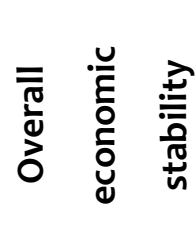 \\
\hline By regions: & 0,21 & 0,32 & 0,84 & 0,50 & 0,51 & 0,65 & 0,71 & 062403 \\
\hline Andijan city. & 0,25 & 0,76 & 0,79 & 0,15 & 0,22 & 0,70 & 0,88 & 0,53655 \\
\hline Khanabad city. & 0,17 & 0,81 & 0,92 & 0,79 & 0,84 & 0,42 & 0,32 & 0,6109 \\
\hline Andijan district & 0,67 & 0,07 & 0,88 & 0,74 & 0,44 & 0,73 & 0,61 & 0,58983 \\
\hline Asaka district & 0,05 & 0,40 & 0,96 & 0,73 & 0,52 & 0,73 & 0,66 & 0,57806 \\
\hline Balikchi district & 0,75 & 0,51 & 0,93 & 0,79 & 0,71 & 0,12 & 0,45 & 0,60814 \\
\hline $\begin{array}{ll}\text { Boston } & (\mathrm{Boz}) \\
\text { district } & \end{array}$ & 0,62 & 0,41 & 1,00 & 0,52 & 0,79 & 0,39 & 0,68 & 0,63176 \\
\hline Buloqboshi district & 0,83 & 0,53 & 1,00 & 0,77 & 0,68 & 0,39 & 0,71 & 0,7002 \\
\hline Jalaquduq district & 0,52 & 0,56 & 0,49 & 0,57 & 0,81 & 0,73 & 0,79 & 0,64052 \\
\hline Izboskan district & 0,53 & 0,40 & 1,00 & 0,74 & 0,78 & 0,70 & 0,67 & 0,68779 \\
\hline Ulugnor district & 0,46 & 0,11 & 0,20 & 0,57 & 0,52 & 0,67 & 0,24 & 0,39382 \\
\hline Kurgantepa district & 0,63 & 0,39 & 0,63 & 0,72 & 0,81 & 0,69 & 0,56 & 0,63233 \\
\hline Marhamat district & 0,67 & 0,40 & 0,85 & 0,65 & 0,78 & 0,71 & 0,58 & 0,66272 \\
\hline Oltinkul district & 0,65 & 0,41 & 0,97 & 0,57 & 0,91 & 0,72 & 0,76 & 0,71296 \\
\hline
\end{tabular}


The American Journal of Management and Economics Innovations

(ISSN - 2693-0811)

Published: December 31, 2020 | Pages: 48-55

Doi: https://doi.org/10.37547/tajmei/Volume02Issue12-07

\begin{tabular}{|l|c|c|c|c|c|c|c|c|}
\hline $\begin{array}{l}\text { Pakhtaobod } \\
\text { district }\end{array}$ & 0,82 & 0,37 & 0,91 & 0,54 & 0,82 & 0,77 & 0,48 & 0,67278 \\
\hline Khojaabad district & 0,74 & 0,40 & 0,74 & 0,63 & 0,69 & 0,55 & 0,32 & 0,58267 \\
\hline Shahrikhan district & 0,81 & 0,58 & 0,96 & 0,77 & 0,64 & 0,64 & 0,82 & 0,74349 \\
\hline
\end{tabular}

Source: Author's calculations based on the data of the Main Department of Statistics of Andijan region.

The main supplier of raw materials for industrial products is agriculture. However, a number of specific features were identified when assessing the sustainability of these sectors. In Ulugnor district, where cotton and wheat yields are low, sustainability was also relatively low. Economic stability was also assessed on the basis of changes in the share of small businesses in the remaining sectors and industries.

When the overall economic stability was determined, the average in the region was 0.62 units. The highest rates were in Shahrikhan (0.74), Altynkul (0.71) and Bulakbashi (0.70) districts. The lower than average values were in
Ulugnor (0.39), Asaka (0.58), Andijan (0.59), Khojaabad (0.58) districts and Andijan (0.54) was determined by our calculations that it was a farm and a paid service.

In ensuring the economic stability of small business, its investment support, capital investments in this area play an important role. In particular, our research has shown that the main reason for the termination of small businesses in Andijan region is the lack of funds, i.e. financial problems. Therefore, a separate assessment of financial stability is appropriate. The level of investment orientation in small business was studied as a key indicator in assessing financial stability.

Table 2

The level of financial stability of small business entities in the districts and cities of Andijan region

\begin{tabular}{|l|c|c|c|}
\hline & $2010-2014$ & $2015-2019$ & Financial stability \\
\hline By regions: & 0,36 & 0,48 & 0,41 \\
\hline Andijan city. & 0,43 & 0,13 & 0,31 \\
\hline Khanabad city. & 0,51 & 0,27 & 0,42 \\
\hline Andijan district & 0,60 & 0,48 & 0,55 \\
\hline Asaka district & 0,01 & 0,06 & 0,03 \\
\hline Balikchi district & 0,69 & 0,71 & 0,70 \\
\hline
\end{tabular}


The American Journal of Management and Economics Innovations

(ISSN - 2693-0811)

Published: December 31, 2020 | Pages: 48-55

2020: $5 \cdot 307$

Doi: https://doi.org/10.37547/tajmei/Volume02Issue12-07

\begin{tabular}{|l|c|c|c|}
\hline $\begin{array}{l}\text { Boston } \\
\text { district }\end{array}$ & 0,82 & 0,58 & 0,72 \\
\hline Buloqboshi district & 0,81 & 0,63 & 0,74 \\
\hline Jalaquduq district & 0,67 & 0,67 & 0,67 \\
\hline Izboskan district & 0,65 & 0,78 & 0,70 \\
\hline Ulugnor district & 0,20 & 0,45 & 0,30 \\
\hline Kurgantepa district & 0,69 & 1,00 & 0,82 \\
\hline Marhamat district & 0,68 & 0,58 & 0,64 \\
\hline Oltinkul district & 0,60 & 0,67 & 0,63 \\
\hline Pakhtaobod district & 0,60 & 0,63 & 0,61 \\
\hline Khojaabad district & 0,70 & 0,69 & 0,70 \\
\hline Shahrikhan district & 0,71 & 0,83 & 0,76 \\
\hline
\end{tabular}

Source: Author's calculations based on the data of the Main Department of Statistics

of Andijan region.

The highest values of financial stability of small business were in Kurgantepa (0.82), Shahrikhan (0.76), Bulakbashi (0.74), Bostan (0.72) districts. Based on our calculations, it was determined that the values below the average values (0.57) correspond to Asaka (0.03), Ulugnor (0.30) districts and the cities of Andijan and Khanabad (Table 2).

Based on the correlation-regression analysis, it was found that the indicators of financial stability reflect a strong dependence on economic stability. Economic and financial factors, i.e. extensive indicators, are also strongly influenced. This requires special attention to the efficiency aspects of the industry, the study of its factors and sources. We know that the result of the activity of an economic entity is the products created by them.

The change in product volume depends on two different conditions. First, the availability of resources, raw materials and the level of sufficiency are important for the growth and development of the production process, and secondly, the market for the product created, that is, its sale, is important. It should also be noted that the change in product volume is related to the second condition. This is due to the fact that recent research pays special attention to the existence of markets in the development of forecast parameters. For this reason, we evaluate not only domestic but also foreign markets separately. After all, we pay special attention to the level of sales of products that create the industry as one of the intensive indicators of efficiency.

The level of realization of a small business includes both quantitative and qualitative aspects. In this case, the quantitative aspects are assessed by the volume of production and demand in the domestic market, while quality is determined by the results of foreign economic activity. This requires an assessment 
of the sustainability of small business in terms of foreign economic activity. Sustainability in foreign economic activity was studied on the basis of trends in export and import growth rates in two directions. The average (0.42) was higher than the overall size (0.37) in the region. Compared to the situation in the region, the smallest units were in the city of Khanabad (0.11), Asaka (0.24), Boston (0.29), Izboskan (0.32), Ulugnor (0.32), Bulakbashi (0.34) districts. .

The level of export stability also reflects low values in the above regions. The reasons for this are traditional processes. In particular, the main exporters are large enterprises, most of which are small businesses processing agricultural products and creating textile products. That is, we argue that these products do not have a high added value and are laborintensive products. Areas with a high level of stability, assessed on the basis of imports, occurred due to the transfer of fixed assets, technology. In particular, the analysis of foreign investment and credit flows in these regions shows a direct correlation with this level of stability.

The state of the stability coefficient in relation to total foreign trade in the region reflects a high correlation with imports. We also found a strong correlation coefficient with foreign investment when analyzing this indicator factor. Nevertheless, the potential of the labor factor is important in the realization of modern equipment, advanced foreign technology.

The coefficient of stability, which was assessed on the basis of labor relations, was implemented in two directions. They are social and institutional coefficients. When we identified institutional stability, the highest situation was in the city of Andijan. The smallest unit corresponds to Izboskan (0.05) district. Also, when we calculated social stability, the highest indicators were in the cities of Khanabad (0.66), Andijan (0.63), and the lowest indicators were in Asaka district (0.38).

Based on all the above indicators of stability, when we assessed the overall stability of small businesses in Andijan region, the average regional indicator was 0.42 units. However, in 16 districts and cities compared to the regional level, cases above the average (0.471) were recorded in 7 districts. The lowest rates were in Asaka district (0.286) and Khanabad city (0.355) (Table 3).

Areas where the overall level of stability reflects high values are strongly linked to the level of stability in financial and foreign economic activity. Regions with low coefficients of stability were found to have a strong correlation with institutional stability.

Table 3

The overall level of stability of small business entities in the districts and cities of Andijan region

\begin{tabular}{|l|c|c|c|c|c|c|}
\hline Indicator name & $\begin{array}{c}\text { Overall } \\
\text { economic } \\
\text { stability }\end{array}$ & $\begin{array}{c}\text { Social } \\
\text { stability }\end{array}$ & $\begin{array}{c}\text { Financial } \\
\text { stability }\end{array}$ & $\begin{array}{c}\text { Stability } \\
\text { based on } \\
\text { TIF }\end{array}$ & $\begin{array}{c}\text { Institutiona } \\
\text { I stability }\end{array}$ & $\begin{array}{c}\text { Overall } \\
\text { stability } \\
\text { level }\end{array}$ \\
\hline By regions: & 0,533 & 0,50 & 0,408 & 0,372 & 0,285 & 0,420 \\
\hline
\end{tabular}


The American Journal of Management and Economics Innovations (ISSN - 2693-0811)

Published: December 31, 2020 | Pages: 48-55

Doi: https://doi.org/10.37547/tajmei/Volume02Issue12-07

\begin{tabular}{|c|c|c|c|c|c|c|}
\hline Andijan city. & 0,537 & 0,63 & 0,312 & 0,371 & 0,829 & 0,536 \\
\hline Khanabad city. & 0,611 & 0,66 & 0,418 & 0,106 & 0,183 & 0,395 \\
\hline Andijan district & 0,590 & 0,40 & 0,554 & 0,430 & 0,219 & 0,439 \\
\hline Asaka district & 0,578 & 0,38 & 0,026 & 0,242 & 0,208 & 0,286 \\
\hline Balikchi district & 0,608 & 0,46 & 0,699 & 0,430 & 0,290 & 0,497 \\
\hline $\begin{array}{ll}\text { Boston } & (\mathrm{Boz}) \\
\text { district } & \end{array}$ & 0,632 & 0,43 & 0,724 & 0,285 & 0,312 & 0,477 \\
\hline $\begin{array}{l}\text { Buloqboshi } \\
\text { district }\end{array}$ & 0,700 & 0,46 & 0,736 & 0,339 & 0,055 & 0,457 \\
\hline $\begin{array}{l}\text { Jalaquduq } \\
\text { district }\end{array}$ & 0,641 & 0,46 & 0,666 & 0,471 & 0,138 & 0,474 \\
\hline Izboskan district & 0,688 & 0,59 & 0,705 & 0,324 & 0,047 & 0,470 \\
\hline Ulugnor district & 0,394 & 0,51 & 0,298 & 0,323 & 0,481 & 0,402 \\
\hline $\begin{array}{l}\text { Kurgantepa } \\
\text { district }\end{array}$ & 0,632 & 0,51 & 0,816 & 0,700 & 0,218 & 0,576 \\
\hline $\begin{array}{l}\text { Marhamat } \\
\text { district }\end{array}$ & 0,663 & 0,42 & 0,640 & 0,654 & 0,266 & 0,529 \\
\hline Oltinkul district & 0,713 & 0,44 & 0,627 & 0,468 & 0,272 & 0,503 \\
\hline $\begin{array}{l}\text { Pakhtaobod } \\
\text { district }\end{array}$ & 0,673 & 0,50 & 0,610 & 0,456 & 0,100 & 0,468 \\
\hline $\begin{array}{l}\text { Khojaabad } \\
\text { district }\end{array}$ & 0,583 & 0,52 & 0,696 & 0,513 & 0,337 & 0,530 \\
\hline $\begin{array}{l}\text { Shahrikhan } \\
\text { district }\end{array}$ & 0,743 & 0,45 & 0,756 & 0,651 & 0,137 & 0,548 \\
\hline
\end{tabular}

Source: Author's calculations based on the data of the Main Department of Statistics of Andijan region. 


\section{CONCLUSIONS AND SUGGESTIONS}

Thus, in recent years, quantitative factors have a strong impact on the stability and balanced development of small businesses in the districts and cities of Andijan region. That is, the number of people employed in small businesses is greatly affected. However, it was found that the impact of intensive factors was strong in highly stable regions where efficiency increases were observed. In particular, it reflects the high dependence of manufactured goods on the level of high value-added and quality of demand in the world market.

Based on the above analysis, special attention should be paid to quantitative indicators to increase the efficiency of production and sustainable development of small business in Andijan region. At the same time, it is necessary to expand the number of infrastructure facilities and services in the region. It is also necessary to introduce institutional changes, including tax and other incentives aimed at introducing a long-term loan regime. At the same time, it is necessary to report on the financial stability of small businesses and introduce benefits based on their export potential and share in employment. As a result of these measures, the profitability of the industry will increase, investment attractiveness will improve, and as a result, the volume and quality of directed capital will increase.

In particular, the assessment of foreign economic activity of small businesses revealed a volatile trend in the regions. Its change indicators did not reflect stability. This requires the identification of priority products by assessing the export potential of districts and cities of the region. The region has sufficient resources to increase the export potential of the textile industry. At the same time, it is necessary to expand the food industry, which processes agricultural raw materials. One of the effective ways to do this is to attract foreign investment and loans in these areas.

\section{REFERENCES}

1. Decree of the President of the Republic of Uzbekistan "On the Action Strategy for further development of the Republic of Uzbekistan" № 4947 February 7, 2017.

2. Lyamanova E.A., Kolpakova K.V., Gusarova E.V. Factors and conditions for ensuring the competitiveness of small business in the Republic of Mordovia

3. Lino Marquez Coimbra. "Theoretical and methodological foundations of entrepreneurship and its importance in the development of the economy of Mozambique" // Vestnik TSU, issue 3 (143), 2015.

4. Savichev A.A. "Factors and conditions for sustainable development of small and medium-sized businesses" // Bulletin of the University. 2015, No. 4. P. 144-149. 